
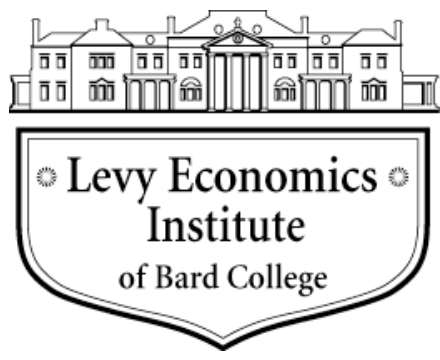

Working Paper No. 881

\title{
The Long-run Determinants of Indian Government Bond Yields
}

by

\author{
Tanweer Akram* \\ Thrivent Financial
}

Anupam Das

Mount Royal University

January 2017

\begin{abstract}
* Tanweer Akram is director of global public policy and economics at Thrivent Financial. Anupam Das is associate professor in the department of economics, justice, and policy studies at Mount Royal University, Alberta, Canada. Disclaimer: The authors' institutional affiliations are provided solely for identification purposes. Views expressed are solely those of the authors and the standard disclaimer applies. The views are not necessarily those of Thrivent Financial, Thrivent Investment Management, or any affiliates. This is for information purposes only and should not be construed as an offer to buy or sell any investment product or service. Disclosure: Akram's employer, Thrivent Financial, invests in a wide range of securities. Asset management services are provided by Thrivent Asset Management, LLC, a wholly owned subsidiary of Thrivent Financial for Lutherans. Note: The data set used in the empirical part of this paper is available upon request to bona fide researchers for replication and verification of the results.
\end{abstract}

The Levy Economics Institute Working Paper Collection presents research in progress by Levy Institute scholars and conference participants. The purpose of the series is to disseminate ideas to and elicit comments from academics and professionals.

Levy Economics Institute of Bard College, founded in 1986, is a nonprofit, nonpartisan, independently funded research organization devoted to public service. Through scholarship and economic research it generates viable, effective public policy responses to important economic problems that profoundly affect the quality of life in the United States and abroad.

Levy Economics Institute

P.O. Box 5000

Annandale-on-Hudson, NY 12504-5000

http://www.levyinstitute.org

Copyright (C) Levy Economics Institute 2017 All rights reserved

ISSN 1547-366X 


\begin{abstract}
This paper investigates the long-term determinants of Indian government bonds' (IGB) nominal yields. It examines whether John Maynard Keynes's supposition that short-term interest rates are the key driver of long-term government bond yields holds over the long-run horizon, after controlling for various key economic factors such as inflationary pressure and measures of economic activity. It also appraises whether the government finance variable - the ratio of government debt to nominal income - has an adverse effect on government bond yields over a long-run horizon. The models estimated here show that in India, short-term interest rates are the key driver of long-term government bond yields over the long run. However, the ratio of government debt and nominal income does not have any discernible adverse effect on yields over a long-run horizon. These findings will help policymakers in India (and elsewhere) to use information on the current trend in short-term interest rates, the federal fiscal balance, and other key macro variables to form their long-term outlook on IGB yields, and to understand the implications of the government's fiscal stance on the government bond market.
\end{abstract}

Keywords: Government Bond Yields; Interest Rates; Monetary Policy; India JEL Classifications: E43, E50, E60, G10, G12, O16 


\section{SECTION I: INTRODUCTION}

John Maynard Keynes (1930) contends that a central bank's monetary policy is the most important driver of long-term interest rates. He believes that the central bank's actions influence long-term interest rates, primarily through the effect of the policy rates on short-term interest rates and other tools of monetary policy. In the General Theory, Keynes (2007 [1936]) reiterates the importance of central bank's influence on long-term interest rates, even though he acknowledges that interest rates have psychological, social, and conventional foundations and arise from investors' liquidity preferences.

This paper examines whether Keynes's conjecture that short-term interest rates are the key driver of long-term government bond yields holds in India over the long term after controlling for various key economic factors, such as inflationary pressure and measures of economic activity. It also appraises if public finance variables, such as the ratio of government debt to nominal income, have an adverse effect on government bond yields in India. Akram and Das (2015a and 2105b) report that Keynes's conjectures hold in India for the short-run horizon. They also find that government finance variables do not appear to exert upward pressure on Indian government bond yields. However, in that study they do not examine if these results hold over a long horizon.

Understanding the determinants of government bond yields in India over the long-run horizon is an important question. This question is important not just for scholarly reasons but also for policy purposes and policy modelling, particularly for discerning the effects of fiscal and monetary policy on government bond yields. Understanding the drivers of government bond yields in emerging markets, such as India, is a crucial question for determining the government finance and macroeconomic policy mix. It is also relevant for fixed income investment and portfolio allocation, as well as the management of government debt.

This paper investigates whether Keynes's conjecture that short-term rates drive long-term interest rates holds over the long-run horizon in the case of India. The paper is organized as follows. Section II discusses Keynes's view on interest rates, provides the theoretical framework, and a simple model. Section III describes the data, the behavioral equations to be estimated, and 
the econometric methodology applied here. Section IV reports the empirical findings. Section V analyzes the policy implications of the results and concludes.

\section{SECTION II: THE THEORETICAL FRAMEWORK, A MODEL, AND INSTITUTIONAL BACKGROUND}

\section{The Keynesian Framework}

This paper investigates the long-run determinants of Indian government bonds based on Keynes's (1930 and 2007 [1936]) view. Keynes holds that the central bank's actions play the decisive role in setting the long-term interest rates on government bonds (Kregel 2011). He argues against the classical view of interest rates based on the loanable funds views, as represented in Cassel (1903), Marshall (1890), Taussig (1918), and the classical economists.

The central bank's ability to influence long-term interest rates arises from its ability to set the policy rates and anchor short-term rates around the policy rates, and to use various other tools of monetary policy (Keynes 1930). He acknowledges that interest rates have a foundation based on human psychology, social conventions, herd mentality, and liquidity preferences (Keynes 2007 [1936]). Nevertheless the most immediate and important driver of long-term government bond yields are the central bank's actions, as manifested through its ability to: (1) influence the shortterm interest rates by setting the policy rates; and (2) use a wide range of tools of monetary policy, including expanding and contracting its balance sheet as it deems appropriate. Keynes relies on Winfried Riefler's (1930) pioneering empirical analysis of the behavior of interest rates on U.S. government securities (Kregel 2011). He also observes that current conditions and the investor's near-term outlook affect the investor's long-term outlook. Keynes believes that since the investor does not have a firm basis for estimating the mathematical expectations of the unknown and uncertain future, the investor resorts to forming an outlook of the future based on the past and current conditions. As a result the factors that affect short-term interest rates also affect long-term interest rates. 
Keynes's view on the drivers of long-term government bond yields is in contrast to that of conventional views in macroeconomics and finance. The conventional view is that government debts and deficits have a decisive effect on government bond yields. Other things held constant, if government debt and/or government deficit (both as a share of national income) increases (decreases), then government bond yields will rise (decline). The conventional view relies on a loanable funds view of interest rates, whereas for Keynes liquidity preferences and the central bank's actions are largely responsible for interest rates as manifested in the yield curve for giltedged (government) securities and other fixed income instruments in an economy.

The conventional view, based on loanable funds theory, is widely represented in the theoretical and empirical literature. Baldacci and Kumar (2010), Gruber and Kamin (2012), Lam and Tokuoka (2013), Poghosysan (2014), and Tokuoka (2012) represent the conventional view. In contrast Akram (2014), Akram and Das (2014a, 2014b, 2015a, and 2015b), and Akram and Li (2016 and 2017) have argued that short-term interest rates and inflation are the key drivers of interest rates on government bonds. Moreover, they argue that if other things are held constant, the government finance variable has hardly any influence on government bond yields. Their view is based on their interpretation of Keynes and is supported with empirical work on the determinants of government bond yields in Japan, the United States, and India. As mentioned earlier, Akram and Das's (2015a and 2015b) empirical work on India has merely explored the short-run dynamics. This paper examines whether the same hypothesis holds true for India in the long run.

\section{A Simple Model of Government Bond Yields}

A simple model, based on Akram and Das (2015b) and Akram and Li's (2017) interpretations of Keynes's views, is presented here. To simplify the exposition, a two-period horizon is used. There are two periods, $t=1,2$. The long-term interest rate on a government bond in period 1 is $r_{L T}$; the short-term interest rates on a Treasury bill in period 1 and period 2 are, respectively, $r_{1}$ and $r_{2}$; the expected short-term interest rate in period 2 is $\mathbb{E} r_{2}$; the 1-year, 1-year forward rate is $f_{1,1}$; the term premium is $z$; the current rate of inflation in period 1 is $\pi_{1}$; the actual rate of inflation in period 2 is $\pi_{2}$; the expected rate of inflation in period 2 is $\mathbb{E} \pi_{2}$; the current growth rate in period 1 is $g_{1}$; the actual growth rate in period 2 is $g_{2}$; the expected growth rate in period 
2 is $\mathbb{E} g_{2}$; the government finance variable in period 1 is $v_{1}$; the government finance variable in period 2 is $v_{2}$; and the expected government finance variable in period 2 is $\mathbb{E} v_{2}$.

The long-term interest rate on the 2-year government bond depends on the short-term interest rate on Treasury bills in period 1 and the 1-year, 1-year forward rate (equation 1.1). The 1-year, 1 -year forward rate is based on the investor's expectation of the short-term interest rate on Treasury bills in period 2 and the term premium (equation 1.2). However, the expected shortterm interest rate on Treasury Bills in period 2 and the term premium is a function of the investor's expected growth and expected inflation in period 2 (equation 1.3). Hence, the 1-year, 1-year forward rate is merely the sum of the expected short-term interest rate on the Treasury bill in period 2 and a function of the expected growth rate and expected inflation in the same period (equation 1.4). This implies that the forward rate is a function of expected short-term interest rates on the Treasury bill, the expected growth rate, and the expected rate of inflation in period 2 (equation 1.5). Since the long-term interest rate is a function of the short-term interest rate on the Treasury bill in period 1 and the 1-year, 1-year forward rate (equation 1.6), it follows that the long-term interest rate is a function of the short-term interest rate in period 1 , and a function of the expected short-term interest rate, the expected growth rate, and the expected rate of inflation in period 2 (equation 1.7).

Keynes's view was that the investors resort to the present and the past and rely on their view of the near-term future to form a view of the long-term future since it is not really possible to have a proper mathematical expectation of the unknown and uncertain future. Hence, for an investor the expected short-term interest rates in period 2 are based on the actual short-term interest rates in period 1 (equation 1.8), the expected growth rate in period 2 is based on the actual growth rate in period 1 (equation 1.9), and the expected rate of inflation in period 2 is based on the actual rate of inflation in period 1 (equation 1.10). Similarly the expected government finance variable in period 2 is based on the government finance variable in period 1 (equation 1.11). These Keynesian assumptions results in a model (equation 1.12) where the long-term interest rate is a function of: (1) the current short-term interest rate, the current growth rate, and the current rate of inflation (equation 1.13); or (2) the current short-term interest rates, the current growth rate, the current rate of inflation, and the current government finance variable (equation 1.14). 
The Keynesian view that the investor's expectation of key economic variables depends largely on current conditions, or on the investor's assessment of current conditions, may appear intriguing and counterintuitive. But if key economic variables follow a Markov process (equations $1.15,1.16,1.17$, and 1.18), then the Keynesian view of the trajectory of expected values of these variables is entirely reasonable. Empirical and behavioral studies of the investor's expectations of interest rates and the expectations of the rate of inflation show that Keynes's conjectures have considerable support (Clark and Davig 2008; Faust and Wright 2013; and Mavroedis, Plagborg-Moller, and Stock 2014).

In contrast, under rational expectations, where Lucasian assumptions of perfect foresight hold, the investor's expected short-term interest rates, expected growth rate, expected rate of inflation, and expected government finance variable would equal, respectively, the actual short-term interest rates, the growth rate, the rate of inflation, and the government finance variable in period 2 (equations 1.19, 1.20,1.21, and 1.21). This would result in long-term interest rates being a function of: (1) the current short-term interest rates, the growth rate, and the rate of inflation in period 2 (equation 1.22); or (2) the current short-term interest rate, the growth rate, the rate of inflation, and the government finance variable in period 2 (equation 1.23).

The model is represented in the following system of equations:

$$
\begin{array}{ll}
\left(1+r_{L T}\right)^{2}=\left(1+r_{1}\right)\left(1+f_{1,1}\right) & \text { equation [1.1] } \\
f_{1,1}=\mathbb{E} r_{2}+z & \text { equation [1.2] } \\
\mathbb{E} r_{2}+z=F^{1}\left(\mathbb{E} g_{2}, \mathbb{E} \pi_{2}\right) & \text { equation [1.3] } \\
f_{1,1}=\mathbb{E} r_{2}+F^{2}\left(\mathbb{E} g_{2}, \mathbb{E} \pi_{2}\right) & \text { equation [1.4] } \\
f_{1,1}=F^{3}\left(\mathbb{E} r_{2}, \mathbb{E} g_{2}, \mathbb{E} \pi_{2}\right) & \text { equation [1.5] } \\
r_{L T}=F^{4}\left(r_{1}, f_{1,1}\right) & \text { equation [1.6] } \\
r_{L T}=F^{4}\left(r_{1}, F^{3}\left(\mathbb{E} r_{2}, \mathbb{E} g_{2}, \mathbb{E} \pi_{2}\right)\right) & \text { equation [1.7] }
\end{array}
$$


The Keynesian assumptions imply that the following holds:

$\mathbb{E} r_{2}=r_{1}$

equation [1.8]

$\mathbb{E} g_{2}=g_{1}$

equation [1.9]

$\mathbb{E} \pi_{2}=\pi_{1}$

equation [1.10]

$\mathbb{E} v_{2}=v_{1}$

equation [1.11]

Incorporating Keynesian assumptions into the model leads to the following:

$r_{L T}=F^{4}\left(r_{1}, F^{3}\left(r_{1}, g_{1}, \pi_{1}\right)\right)$

equation [1.12]

$r_{L T}=F^{5}\left(r_{1}, g_{1}, \pi_{1}\right)$

equation [1.13]

Extending the model to include a government finance variable results in the following:

$r_{L T}=F^{6}\left(r_{1}, g_{1}, \pi_{1}, v_{1}\right)$

equation [1.14]

If the variables in period 2 are to follow simple Markov processes, these variables can be modeled in the following terms:
$r_{2}=\Lambda_{1}+\Lambda_{2} r_{1}$
equation [1.15]
$g_{2}=\Lambda_{3}+\Lambda_{4} g_{1}$
equation [1.16]
$\pi_{2}=\Lambda_{5}+\Lambda_{6} \pi_{1}$
equation [1.17]
$v_{2}=\Lambda_{7}+\Lambda_{8} v_{1}$
equation [1.18]

In the above equations, the restrictions on the parameters are as follows: $\Lambda_{2}<1, \Lambda_{4}<1, \Lambda_{6}<$ 1 , and $\Lambda_{8}<1$. 
It is useful to contrast the Keynesian model with a Lucasian (rational expectations) model. Under rational expectations:

$\mathbb{E} r_{2}=r_{2} \quad$ equation [1.19]

$\mathbb{E} g_{2}=g_{2} \quad$ equation [1.20]

$\mathbb{E} \pi_{2}=\pi_{2} \quad$ equation [1.21]

$\mathbb{E} v_{2}=v_{2} \quad$ equation [1.22]

Under a Lucasian assumption, the long-term rates are modeled, respectively, without and with a government finance variable, as follows:

$r_{L T}=F^{7}\left(r_{1}, r_{2}, g_{2}, \pi_{2}\right)$

equation [1.23]

$r_{L T}=F^{8}\left(r_{1}, r_{2}, g_{2}, \pi_{2}, v_{2}\right)$

equation $[1.24]$

\section{Institutional Background}

Akram and Das (2015a and 2015b) provide the institutional background to the monetary policy framework, government bond market, and monetary-fiscal coordination in India. Yanamandra (2014) gives additional perspective on monetary policymaking in India in light of economic reforms, modernization, and recent developments, while Chakraborty (2016) provides a detailed description and analysis of the country's fiscal-monetary policy mix and monetary-fiscal coordination. Jácome et al.'s (2012) survey of global practices of the central bank's extension of credit and coordination with the national Treasury includes a description of Indian laws, regulations, and practices.

India enjoys monetary sovereignty, as defined by Wray (2012). The Government of India issues its own currency, the rupee. The country's central bank, the Reserve Bank of India (RBI), sets policy rates and can use a wide range of monetary policy tools. The RBI enjoys a wide range of authority and control over the country's financial system. The Government of India has the legal and political authority to collect taxes from households, businesses, financial institutions, and other organizations. The country's sovereign debt is predominantly issued in its own currency, 
the rupee. The multifaceted roles played by the RBI in the payment system, monetary policy, financial stability policy, and policy coordination with the Treasury gives it the operational ability to influence nominal yields of government bonds by setting and changing short-term interest rates and using other tools of monetary policy as it deems appropriate.

The next section introduces the behavioral equations, time-series data, and econometric methods to be used in examining the importance of short-term interest rates, government finance variables, and other key macroeconomic variables in determining the nominal yields on Indian government bonds over the long-run horizon.

\section{SECTION III: DATA, BEHAVIORAL EQUATIONS, AND METHODS}

\section{Data}

For the purpose of econometric estimations, time-series data on the nominal yields of long-term Indian government bonds (IGBs), short-term interest rates, the rate of inflation, the growth of industrial production, and government finance variables are used. Nominal yields on Indian Treasury bills of 3-month maturities are used for the short-term interest rates, while the nominal yields on IGBs - such as yields on IGBs of 2-year, 3-year, 5-year, 7-year, and 10-year maturities - are used to represent the long-term government bond yields. Figure 1 shows the evolution of the nominal yields of IGBs. Figure 2 shows the evolution of short-term interest rates along with the RBI's policy rates. The rate of inflation is defined as the year-over-year percentage change in the Consumer Price Index (CPI) for all items. Growth in industrial production is the year-over-year change in the index of industrial activity in India. The ratio of government debt and nominal GDP measures the government variable finance. Data is collected from Macrobond's (various years) data services. Table 1 provides a summary of the data and a detailed description of the variables used here. The monthly time-series dataset runs from 2003M03 to 2015M11, while the quarterly dataset includes time-series variables from 2003Q3 to 2015 Q3. 
Figure 1: The Evolution of Indian Government Bond Yields

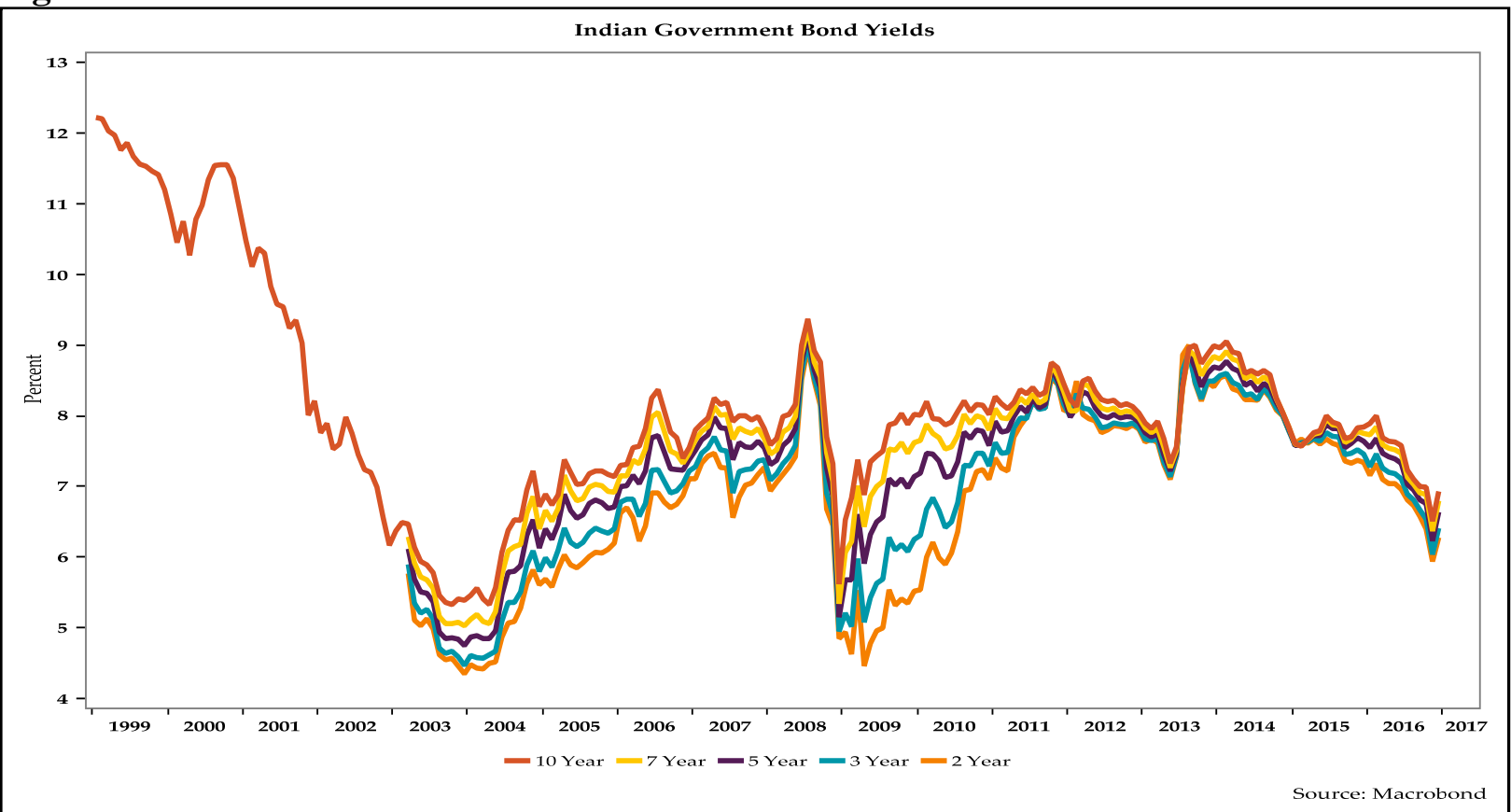

Figure 2: Policy Rate and Short-term Interest Rates in India

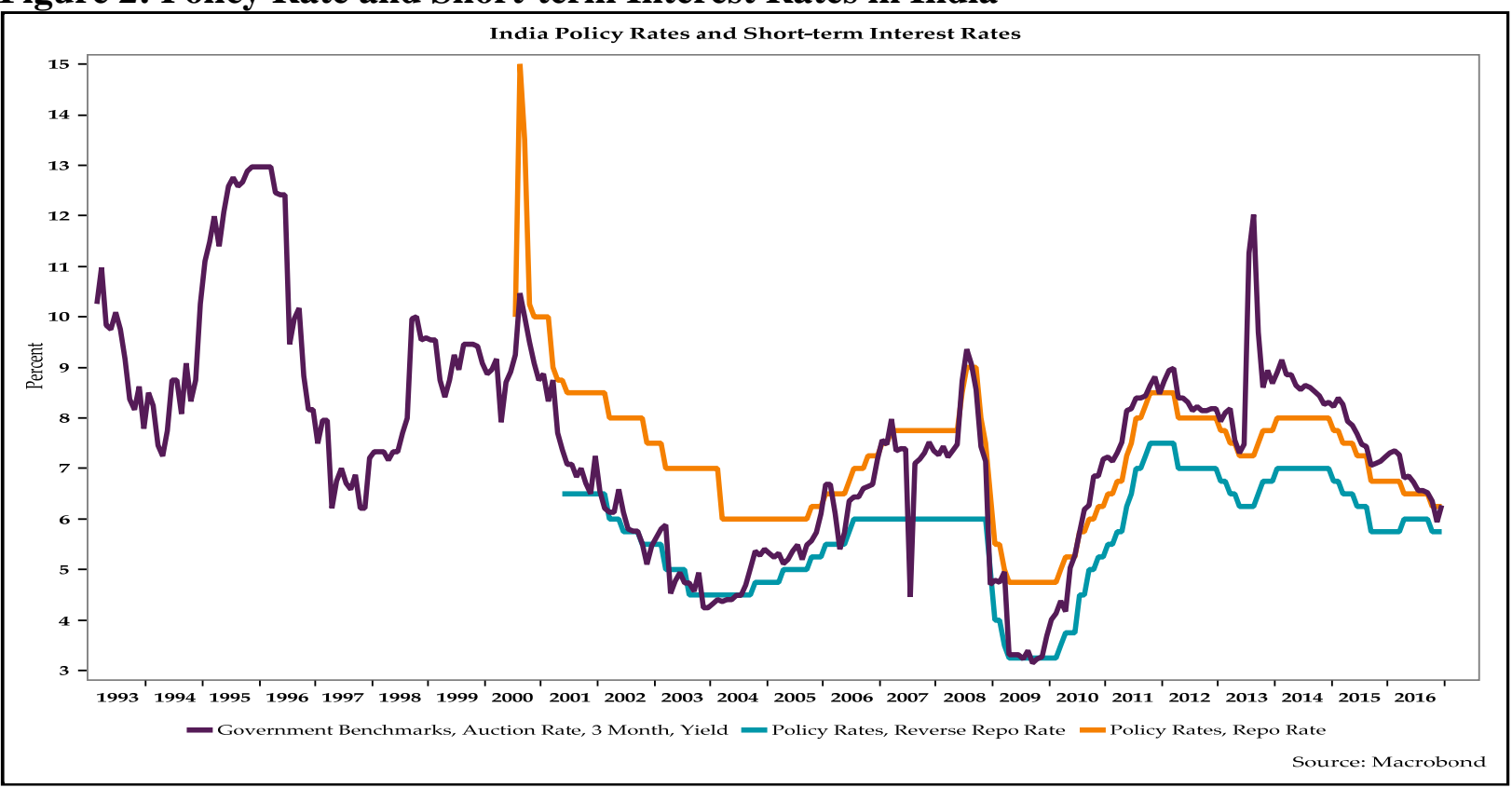


Table 1: Summary of the Data and the Variables

\begin{tabular}{|c|c|c|c|}
\hline $\begin{array}{l}\text { Variable } \\
\text { Labels }\end{array}$ & Data Description, Date Range & Frequency & Sources \\
\hline \multicolumn{4}{|c|}{ Indian Short-term Interest Rates } \\
\hline $\begin{array}{l}\text { TB3M; } \\
\text { TB3M_Q }\end{array}$ & $\begin{array}{l}\text { Government Benchmarks, Auction } \\
\text { Rate, } 3 \text { Month,\%, Yield; } \\
\text { Jan 1999-Oct 2015; } \\
\text { 1Q 1999-3Q 2015 }\end{array}$ & $\begin{array}{l}\text { Daily; converted } \\
\text { to monthly; } \\
\text { converted to } \\
\text { quarterly }\end{array}$ & $\begin{array}{l}\text { Reserve Bank of } \\
\text { India; Macrobond }\end{array}$ \\
\hline \multicolumn{4}{|c|}{ Indian Government Bond Yields } \\
\hline $\begin{array}{l}\text { IGB2YR; } \\
\text { IGB2YR_Q }\end{array}$ & $\begin{array}{l}\text { Government bond, } 2 \text { year, \% yield; } \\
\text { Mar 2003-Oct 2015; } \\
\text { 2Q 2003-3Q 2015 }\end{array}$ & $\begin{array}{l}\text { Daily; converted } \\
\text { to monthly; } \\
\text { converted to } \\
\text { quarterly }\end{array}$ & $\begin{array}{l}\text { Clearing } \\
\text { Corporation of } \\
\text { India; Macrobond }\end{array}$ \\
\hline $\begin{array}{l}\text { IGB3YR; } \\
\text { IGB3YR_Q }\end{array}$ & $\begin{array}{l}\text { Government bond,, } 3 \text { year, \% } \\
\text { yield; } \\
\text { Mar 2003-Oct 2015; } \\
\text { 2Q 2003-3Q 2015 }\end{array}$ & $\begin{array}{l}\text { Daily; converted } \\
\text { to monthly; } \\
\text { converted to } \\
\text { quarterly }\end{array}$ & $\begin{array}{l}\text { Clearing } \\
\text { Corporation of } \\
\text { India; Macrobond }\end{array}$ \\
\hline $\begin{array}{l}\text { IGB5YR; } \\
\text { IGB5YR_Q }\end{array}$ & $\begin{array}{l}\text { Government bond, } 5 \text { year, \% yield; } \\
\text { Mar 2003-Oct 2015; } \\
\text { 2Q 2003-3Q 2015 }\end{array}$ & $\begin{array}{l}\text { Daily; converted } \\
\text { to monthly; } \\
\text { converted to } \\
\text { quarterly }\end{array}$ & $\begin{array}{l}\text { Clearing } \\
\text { Corporation of } \\
\text { India; Macrobond }\end{array}$ \\
\hline $\begin{array}{l}\text { IGB7YR; } \\
\text { IGB7YR_Q }\end{array}$ & $\begin{array}{l}\text { Government bond, } 7 \text { year, \% yield; } \\
\text { Mar 2003-Oct 2015; } \\
\text { 2Q 2003-2Q 2015 }\end{array}$ & $\begin{array}{l}\text { Daily; converted } \\
\text { to monthly; } \\
\text { converted to } \\
\text { quarterly }\end{array}$ & $\begin{array}{l}\text { Clearing } \\
\text { Corporation of } \\
\text { India; Macrobond }\end{array}$ \\
\hline $\begin{array}{l}\text { IGB10YR; } \\
\text { IGB10YR_Q }\end{array}$ & $\begin{array}{l}\text { Government bonds, } 10 \text { year, \%, } \\
\text { yield; } \\
\text { Jan 1999-Oct 2015; } \\
\text { 1Q 1999-2 } 2015\end{array}$ & $\begin{array}{l}\text { Daily; converted } \\
\text { to monthly; } \\
\text { converted to } \\
\text { quarterly }\end{array}$ & $\begin{array}{l}\text { Clearing } \\
\text { Corporation of } \\
\text { India; Macrobond }\end{array}$ \\
\hline \multicolumn{4}{|l|}{ Inflation } \\
\hline $\begin{array}{l}\text { TCPIYOY; } \\
\text { TCPIYOY_Q; }\end{array}$ & $\begin{array}{l}\text { India, Consumer Price Index, The } \\
\text { Economist, Total, \% change, y/y } \\
\text { Jan 2007-Oct 2015; } \\
\text { 1Q 2007-2Q 2015 }\end{array}$ & $\begin{array}{l}\text { Monthly; } \\
\text { converted to } \\
\text { quarterly }\end{array}$ & $\begin{array}{l}\text { The Economist; } \\
\text { Macrobond }\end{array}$ \\
\hline \multicolumn{4}{|c|}{ Economic Activity } \\
\hline $\begin{array}{l}\text { IPYOY; } \\
\text { IPYOY_Q }\end{array}$ & $\begin{array}{l}\text { Industrial production, \% change, } \\
\text { y/y; } \\
\text { Jan 1999-Oct 2015; } \\
\text { 1Q 1999-2Q 2015 }\end{array}$ & $\begin{array}{l}\text { Monthly; } \\
\text { converted to } \\
\text { quarterly }\end{array}$ & $\begin{array}{l}\text { Central Statistical } \\
\text { Organisation, India; } \\
\text { Macrobond }\end{array}$ \\
\hline \multicolumn{4}{|c|}{ Government Finance } \\
\hline $\begin{array}{l}\text { DEBT_RATIO_ } \\
\text { Q }\end{array}$ & $\begin{array}{l}\text { Government debt, \% of nominal } \\
\text { GDP; } \\
\text { 1Q1999-2Q } 2015\end{array}$ & Quarterly & $\begin{array}{l}\text { Indian Ministry of } \\
\text { Commerce \& } \\
\text { Industry; } \\
\text { Macrobond }\end{array}$ \\
\hline
\end{tabular}


Both monthly and quarterly data are used to examine the determinants of the nominal yields of long-term government bonds. However, it should be noted that Indian government finance data is available only in the quarterly form. Hence, the-debt-to-GDP ratio is included only in the quarterly equations.

\section{Behavioral Equations}

The following behavioral equations for monthly data and for quarterly data are constructed in concordance with the model based on the Keynesian framework presented earlier. These behavioral equations readily lend themselves to empirical testing.

The behavioral equations for the monthly data can be described as follows. The first set of behavioral equations consists of only one explanatory variable. The long-term interest rate on government bonds depends only on the short-term interest rate (equation 2.1), inflation (equation 2.2), or the growth rate (equation 2.3). The second set of behavioral equations consists of two explanatory variables. The long-term interest rate on government bonds depends on the shortterm interest rate and the rate of inflation (equation 2.4) or the short-term interest rates and the growth rate (equation 2.5). The third set of behavioral equations consists of all three explanatory variables. The long-term interest rate on government bonds depends on the short-term interest rate, the rate of inflation, and the growth rate (equation 2.6).

$$
\begin{array}{llr}
r_{L T}=a_{1}+a_{2} r_{1} & \text { equation [2.1] } \\
r_{L T}=a_{3}+a_{4} \pi_{1} & \text { equation [2.2] } \\
r_{L T}=a_{5}+a_{6} g_{1} & \text { equation [2.3] } \\
r_{L T}=a_{7}+a_{8} r_{1}+a_{79} \pi_{1} & \text { equation [2.4] } \\
r_{L T}=a_{10}+a_{11} r_{1}+a_{12} g_{1} & \text { equation [2.5] } \\
r_{L T}=a_{13}+a_{14} r_{1}+a_{15} \pi_{1}+a_{16} g_{1} & \text { equation [2.6] }
\end{array}
$$

These equations are estimated using monthly data for bond yields of government securities for various tenors using a variety of indicators of short-term interest rates, the rate of inflation, and the growth rate. 
The behavioral equations for the quarterly data incorporate the government finance variables. The first set of equations consists of just two explanatory variables. The long-term interest rate depends on: the short-term interest rate and the government finance variables (equation 2.7); the rate of inflation and the government finance variable (equation 2.8); or the rate of growth and the government finance variable (equation 2.9). The second set consists of three explanatory variables: the short-term interest rate, the rate of inflation, and the government finance variable (equation 2.10); or the short-term interest rate, the growth rate, and the government finance variable (2.11). The third set consists of four explanatory variables: the short-term interest rates, the rate of inflation, the growth rate, and the government finance variable (equation 2.12). The specific-to-general estimation approach for both monthly and quarterly variables is used here.

The following equations are estimated for government bond yields using quarterly data.

$$
\begin{array}{ll}
r_{L T}=z_{1}+z_{2} r_{1}+z_{3} v_{1} & \text { equation [2.7] } \\
r_{L T}=z_{4}+z_{5} \pi_{1}+z_{6} v_{1} & \text { equation [2.8] } \\
r_{L T}=z_{7}+z_{8} g_{1}+z_{9} v_{1} & \text { equation [2.9] } \\
r_{L T}=z_{10}+z_{11} r_{1}+z_{12} \pi_{1}+z_{13} v_{1} & \text { equation [2.10] } \\
r_{L T}=z_{14}+z_{15} r_{1}+z_{16} g_{1}+z_{17} v_{1} & \text { equation [2.11] } \\
r_{L T}=z_{18}+z_{19} r_{1}+z_{20} \pi_{1}+z_{21} g_{1}+z_{22} v_{1} & \text { equation [2.12] }
\end{array}
$$

These equations are estimated using quarterly data for bond yields of government securities for various tenors with short-term interest rates, the rate of inflation, the growth rate, and the government finance variable as explanatory variables.

\section{Econometric Methodology}

The first step in the methodology is to examine the nature of the data. The presence of unit roots in most macroeconomic variables is fairly common (Nelson and Plosser 1982). Hence, estimating long-run relationships of stationary variables using standard cointegration techniques (such as Johansen cointegration) is inconsistent. Therefore, unit root tests on the variables used in this paper are imperative. Both the Augmented Dickey-Fuller (ADF) (Dickey and Fuller 1979 
and 1981) and Phillips-Perron (PP) (Phillips and Perron 1988) tests are conducted. Different versions of ADF and PP tests (with no constant and trend, constant and no trend, and constant and trend) produce similar results. Due to space constraint only the results with no constant and trend are presented here. (However, the remaining results are available upon request.) The results for monthly variables are displayed in table 2 and the results for quarterly variables are displayed in table 3. For the monthly variables, all variables except IPIYOY are non-stationary at levels and stationary at the first difference. Thus most variables are integrated of order one (I(1)). Both $\mathrm{ADF}$ and PP tests suggest that IPIYOY is stationary at levels, that is, I(0). For quarterly variables, all variables are found to be non-stationary at levels and stationary at the first difference, that is, variables are integrated of order one I(1).

Table 2: Unit Root Tests for Monthly Variables

\begin{tabular}{lcc}
\hline Variable & Augmented Dickey-Fuller (ADF) & Phillips-Perron (PP) \\
\hline IGB2YR & 0.07 & 0.02 \\
$\Delta$ IGB2YR & $-11.59^{* * *}$ & $-11.59^{* * *}$ \\
IGB3YR & 0.12 & 0.10 \\
$\Delta$ IGB3YR & $-7.59^{* * *}$ & $-11.56^{* * *}$ \\
IGB5YR & 0.14 & 0.12 \\
$\Delta$ IGB5YR & $-7.87^{* * *}$ & $-11.43^{* * *}$ \\
IGB7YR & 0.14 & -2.06 \\
$\Delta$ IGB7YR & $-7.96^{* * *}$ & $-11.20^{* * *}$ \\
TB3M & -0.98 & -0.96 \\
$\Delta$ TB3M & $-17.12^{* * *}$ & $-17.15^{* * *}$ \\
TCPIYOY & -0.57 & -0.57 \\
$\Delta$ TCPIYOY & $-9.55^{* * *}$ & $-9.53^{* * *}$ \\
IPIYOY & $-2.30^{* *}$ & $-7.01^{* * *}$ \\
$\Delta$ IPIYOY & $-9.74^{* * *}$ & $-47.61^{* * *}$ \\
\hline Notes:*** & &
\end{tabular}

Notes: ${ }^{* * *}$ and ${ }^{* *}$ indicate statistical significance at the 1 percent and 5 percent level, respectively. Null hypothesis of both ADF and PP tests is that the series contains unit root. 
Table 3: Unit Root Tests for Quarterly Variables

\begin{tabular}{lcc}
\hline Variable & Augmented Dickey-Fuller (ADF) & Phillips-Perron (PP) \\
\hline IGB2YR_Q & 0.15 & 0.18 \\
$\Delta$ IGB2YR_Q & $-7.48^{* * *}$ & $-7.48^{* * *}$ \\
IGB3YR_Q & 0.14 & 0.36 \\
AIGB3YR_Q & $-8.09^{* * *}$ & $-8.25^{* * *}$ \\
IGB5YR_Q & 0.11 & 0.49 \\
AIGB5YR_Q & $-8.52^{* * *}$ & $-9.13^{* * *}$ \\
IGB7YR_Q & 0.09 & 0.55 \\
$\Delta$ IGB7YR_Q & $-6.76^{* * *}$ & $-9.52^{* * *}$ \\
IGB10YR_Q & -1.33 & -1.33 \\
$\Delta$ IGB10YR_Q & $-8.82^{* * *}$ & $-8.82^{* * *}$ \\
TB3M_Q & -0.92 & -0.96 \\
$\Delta$ TB3M_Q & $-8.56^{* * *}$ & $-8.64^{* * *}$ \\
TCPIYOY_Q & -0.47 & -0.34 \\
$\Delta$ TCPIYOY_Q & $-6.67^{* * *}$ & $-6.76^{* * *}$ \\
DRATIO_Q & 0.08 & 0.18 \\
$\Delta$ DRATIO_Q & $-2.61^{* * *}$ & $-11.38^{* * *}$
\end{tabular}

Notes: ${ }^{* * *},{ }^{* *}$, and $*$ indicate statistical significance at the 1 percent, 5 percent, and 10 percent level, respectively. Null hypothesis of both ADF and PP tests is that the series contains unit root.

To estimate the long-run cointegrating relationships, a number of techniques-including the autoregressive distributive lag (ARDL) proposed by Pesaran and Shin (1998) and Pesaran, Shin, and Smith (2001), and the Johansen cointegration proposed by Johansen and Juselius (1990) have been used in the existing literature. The ARDL bounds-test approach is based on the ordinary least square (OLS) estimation of a conditional unrestricted error correction model (UECM) for cointegration analysis. The ARDL technique is more appealing than the Johansen cointegration technique because the latter requires that the variables are integrated of the same order of I(1). The ARDL approach, on the contrary, is not constrained by the outcomes of unit root tests. It is applicable irrespective of whether the regressors in the model are purely I(0), purely I(1), or mutually cointegrated. In the present case most variables are I(1) and one is I(0). Moreover, the ARDL technique allows different variables to take different optimal numbers of lags, while this is not permitted in the Johansen cointegration approach. Therefore, the ARDL 
technique, which will accommodate both $\mathrm{I}(0)$ and $\mathrm{I}(1)$ variables, will be used to estimate the long-run relationships between long-term government bond yields and other control variables.

\section{SECTION IV: EMPIRICAL RESULTS}

The ARDL bounds tests results generated from monthly variables are presented in tables 4-8. When the short-term interest rate is included with the inflation variable, in most cases the computed $F$-statistics based on Wald test exceeds the upper bounds value at the 5 percent level. In the case of IGB2YR, the computed $F$-statistics exceeds the upper bounds value at the 10 percent level when the short-term rate is included in the equation with both inflation and an industrial production index (equation 3.6). The null hypothesis of no cointegration is rejected whenever the $F$-statistics value is higher than the upper bounds value. This analysis confirms the

presence of a long-run relationship among long-term government bond yields, short-term interest rates, the rate of inflation, and the growth in industrial production. It enables estimation of the long-run coefficients of short-term interest rates and other control variables. The coefficients of short-term interest rates are always positive and statistically significant at the 1 percent level. The size of this coefficient tends to be smaller as the tenors of government bonds rise. These results, thus, suggest that in the long run the short-term interest rates strongly influence the longterm government bond yields in India. 
Table 4: ARDL Bounds Test Results for IGB2YR (Monthly Data)

\begin{tabular}{lc}
\hline Equation & F-statistics \\
\hline 4 4.1) IGB2YR $=\beta_{0}+\beta_{1}$ TB3M & 3.93 \\
4.2) IGB2YR $=\beta_{2}+\beta_{3}$ TCPIYOY & 2.97 \\
4.3) IGB2YR $=\beta_{4}+\beta_{5}$ IPIYOY & 1.46 \\
4.4) IGB2YR $=\beta_{6}+\beta_{7}$ TB3M+ $\beta_{8}$ TCPIYOY & $\mathbf{6 . 5 2 * *}$ \\
4.5) IGB2YR $=\beta_{9}+\beta_{10}$ TB3M+ $+\beta_{11}$ IPIYOY & 2.99 \\
4.6) IGB2YR $=\beta_{12}+\beta_{13}$ TB3M+ $+\beta_{14}$ TCPIYOY+ $\beta_{15}$ IPIYOY & $\mathbf{4 . 8 1 ^ { * }}$
\end{tabular}

Long-run Relationships

\begin{tabular}{lcc}
\hline Variable & Equation $\mathbf{4 . 4}$ & Equation $\mathbf{4 . 6}$ \\
\hline \multirow{2}{*}{ TB3M } & $0.51^{* * *}$ & $0.51^{* * *}$ \\
& $(0.04)$ & $(0.05)$ \\
TCPIYOY & -0.01 & -0.00 \\
& $(0.04)$ & $(0.04)$ \\
IPIYOY & - & -0.00 \\
& & $(0.01)$ \\
Constant & $3.60^{* * *}$ & $3.60^{* * *}$ \\
& $(0.48)$ & $(0.54)$ \\
\hline Number of Observations & 107 & 105
\end{tabular}

Notes: ${ }^{* *},{ }^{* *}$, and $*$ represent 1 percent, 5 percent, and 10 percent levels of significance, respectively. Standard errors are in the parenthesis. Lower bounds values are 6.84, 4.94, and 4.04 for 1 percent, 5 percent, and 10 percent levels of significance, respectively. Upper bounds values are 7.84, 5.73, and 4.78 for 1 percent, 5 percent, and 10 percent levels of significance, respectively. 
Table 5: ARDL Bounds Test Results for IGB3YR (Monthly Data)

\begin{tabular}{lc}
\hline Equation & F-statistics \\
\hline 4.7$) \mathrm{IGB} 3 Y \mathrm{R}=\beta_{16}+\beta_{17} \mathrm{~TB} 3 \mathrm{M}$ & 4.60 \\
4.8) IGB3YR $=\beta_{18}+\beta_{19} \mathrm{TCPIYOY}$ & 2.64 \\
4.9) IGB3YR $=\beta_{20}+\beta_{21} \mathrm{IPIYOY}$ & 2.03 \\
4.10) IGB3YR $=\beta_{22}+\beta_{23} \mathrm{~TB} 3 \mathrm{M}+\beta_{24} \mathrm{TCPIYOY}$ & $\mathbf{8 . 3 7 ^ { * * * }}$ \\
4.11) IGB3YR $=\beta_{25}+\beta_{26} \mathrm{~TB} 3 \mathrm{M}+\beta_{27}$ IPIYOY & 3.70 \\
4.12) IGB3YR $=\beta_{28}+\beta_{29} \mathrm{~TB} 3 \mathrm{M}+\beta_{30} \mathrm{TCPIYOY}+\beta_{31}$ IPIYOY & $6.20^{* *}$
\end{tabular}

\section{Long-run Relationships}

\begin{tabular}{lcc}
\hline Variable & Equation $\mathbf{4 . 1 0}$ & Equation 4.12 \\
\hline TB3M & $0.39^{* * *}$ & $0.38^{* * *}$ \\
& $(0.04)$ & $(0.05)$ \\
TCPIYOY & -0.01 & -0.01 \\
& $(0.04)$ & $(0.04)$ \\
IPIYOY & - & -0.01 \\
& & $(0.01)$ \\
Constant & $4.74^{* * *}$ & $4.81^{* * *}$ \\
\hline Number of Observations & $(0.47)$ & $(0.55)$ \\
\hline
\end{tabular}

Notes: *** and $* *$ represent 1 percent and 5 percent levels of significance, respectively. Standard errors are in the parenthesis. Lower bounds values are 6.84, 4.94, and 4.04 for 1 percent, 5 percent, and 10 percent levels of significance, respectively. Upper bounds values are 7.84, 5.73, and 4.78 for 1 percent, 5 percent, and 10 percent levels of significance, respectively. 
Table 6: ARDL Bounds Test Results for IGB5YR (Monthly Data)

\begin{tabular}{|c|c|}
\hline Equation & F-statistics \\
\hline 4.13) $\mathrm{IGB} 5 \mathrm{YR}=\beta_{32}+\beta_{33} \mathrm{~TB} 3 \mathrm{M}$ & 3.84 \\
\hline 4.14) IGB5YR $=\beta_{34}+\beta_{35}$ TCPIYOY & 3.65 \\
\hline 4.15) IGB5YR $=\beta_{36}+\beta_{37}$ IPIYOY & 2.37 \\
\hline 4.16) $\mathrm{IGB} 5 \mathrm{YR}=\beta_{38}+\beta_{39} \mathrm{~TB} 3 \mathrm{M}+\beta_{40} \mathrm{TCPIYOY}$ & $10.56^{* * *}$ \\
\hline 4.17) IGB5YR $=\beta_{41}+\beta_{42}$ TB3M+ $\beta_{43}$ IPIYOY & 4.08 \\
\hline 4.18) IGB5YR $=\beta_{44}+\beta_{45} \mathrm{~TB} 3 \mathrm{M}+\beta_{46} \mathrm{TCPIYOY}+\beta_{47} \mathrm{IPIYOY}$ & $7.74^{* *}$ \\
\hline
\end{tabular}

Long-run Relationships

\begin{tabular}{lcc}
\hline Variable & Equation 4.16 & Equation 4.18 \\
\hline TB3M & $0.26^{* * *}$ & $0.25^{* * *}$ \\
& $(0.04)$ & $(0.04)$ \\
TCPIYOY & -0.00 & -0.00 \\
& $(0.04)$ & $(0.04)$ \\
IPIYOY & - & -0.01 \\
& & $(0.01)$ \\
Constant & $5.86^{* * *}$ & $5.98^{* * *}$ \\
& $(0.43)$ & $(0.53)$ \\
\hline Number of Observations & 107 & 105 \\
\hline
\end{tabular}

Notes: *** and ** represent 1 percent and 5 percent levels of significance, respectively. Standard errors are in the parenthesis. Lower bounds values are 6.84, 4.94, and 4.04 for 1 percent, 5 percent, and 10 percent levels of significance, respectively. Upper bounds values are 7.84, 5.73, and 4.78 for 1 percent, 5 percent, and 10 percent levels of significance, respectively. 
Table 7: ARDL Bounds Test Results for IGB7YR (Monthly Data)

\begin{tabular}{lc}
\hline Equation & $F$-statistics \\
\hline 4.19$)$ IGB7YR $=\beta_{48}+\beta_{49} \mathrm{~TB} 3 \mathrm{M}$ & 4.02 \\
4.20) IGB7YR $=\beta_{50}+\beta_{51} \mathrm{TCPIYOY}$ & $\mathbf{5 . 6 3}$ \\
4.21) IGB7YR $=\beta_{52}+\beta_{53} \mathrm{IPIYOY}$ & 2.59 \\
4.22) IGB7YR $=\beta_{54}+\beta_{55} \mathrm{~TB} 3 \mathrm{M}+\beta_{56} \mathrm{TCPIYOY}$ & $\mathbf{1 0 . 6 0 ^ { * * * }}$ \\
4.23) IGB7YR $=\beta_{57}+\beta_{58} \mathrm{~TB} 3 \mathrm{M}+\beta_{59}$ IPIYOY & 4.09 \\
4.24) IGB7YR $=\beta_{60}+\beta_{61} \mathrm{~TB} 3 \mathrm{M}+\beta_{62} \mathrm{TCPIYOY}+\beta_{63}$ IPIYOY & $\mathbf{7 . 7 0 ^ { * * }}$
\end{tabular}

\section{Long-run Relationships}

\begin{tabular}{lccc}
\hline Variable & Equation 4.20 & Equation 4.22 & Equation 4.24 \\
\hline \multirow{2}{*}{ TB3M } & - & $0.19^{* * *}$ & $0.18^{* * *}$ \\
& & $(0.03)$ & $(0.04)$ \\
TCPIYOY & 0.03 & 0.02 & 0.01 \\
& $(0.08)$ & $(0.04)$ & $(0.04)$ \\
IPIYOY & - & - & -0.01 \\
& & & $(0.01)$ \\
Constant & $7.71^{* * *}$ & $6.40^{* * *}$ & $6.53^{* * *}$ \\
& $(0.62)$ & $(0.43)$ & $(0.52)$ \\
\hline Number of Observations & 107 & 107 & 105
\end{tabular}

Notes: $* * *$ and $* *$ represent 1 percent and 5 percent levels of significance, respectively. Standard errors are in the parenthesis. Lower bounds values are 6.84, 4.94, and 4.04 for 1 percent, 5 percent, and 10 percent levels of significance, respectively. Upper bounds values are 7.84, 5.73, and 4.78 for 1 percent, 5 percent, and 10 percent levels of significance, respectively. 
Table 8: ARDL Bounds Test Results for IGB10YR (Monthly Data)

\begin{tabular}{lc}
\hline Equation & F-statistics \\
\hline 4.25$)$ IGB10YR $=\beta_{64}+\beta_{65} \mathrm{~TB} 3 \mathrm{M}$ & 4.73 \\
$4.26) \mathrm{IGB10YR}=\beta_{66}+\beta_{67} \mathrm{TCPIYOY}$ & $\mathbf{7 . 5 1 * *}$ \\
4.27) IGB10YR $=\beta_{68}+\beta_{69} \mathrm{IPIYOY}$ & 3.60 \\
4.28) IGB10YR $=\beta_{70}+\beta_{71} \mathrm{~TB} 3 \mathrm{M}+\beta_{72} \mathrm{TCPIYOY}$ & $\mathbf{9 . 4 2}$ \\
4.29) IGB10YR $=\beta_{73}+\beta_{74} \mathrm{~TB} 3 \mathrm{M}+\beta_{75} \mathrm{IPIYOY}$ & 3.07 \\
$4.30) \mathrm{IGB10YR}=\beta_{76}+\beta_{77} \mathrm{~TB} 3 \mathrm{M}+\beta_{78} \mathrm{TCPIYOY}+\beta_{79} \mathrm{IPIYOY}$ & $\mathbf{6 . 8 3}$
\end{tabular}

\section{Long-run Relationships}

\begin{tabular}{lccc}
\hline Variable & Equation 4.26 & Equation 4.28 & Equation 4.30 \\
\hline TB3M & - & $0.14^{* * *}$ & $0.13^{* * *}$ \\
& 0.04 & $(0.04)$ & $(0.04)$ \\
TCPIYOY & $(0.05)$ & 0.03 & 0.02 \\
& & $(0.04)$ & $(0.04)$ \\
IPIYOY & - & -0.01 \\
& $7.74^{* * *}$ & & $(0.01)$ \\
Constant & $(0.45)$ & $6.87^{* * *}$ & $6.99^{* * *}$ \\
& 107 & $(0.44)$ & $(0.53)$ \\
\hline Number of Observations & 107 & 105
\end{tabular}

Notes: *** and ** represents 1 percent and 5 percent levels of significance, respectively. Standard errors are in the parenthesis. Lower bounds values are 6.84, 4.94, and 4.04 for 1 percent, 5 percent, and 10 percent levels of significance, respectively. Upper bounds values are 7.84, 5.73, and 4.78 for 1 percent, 5 percent, and 10 percent levels of significance, respectively. 
Estimated results using quarterly data are presented in tables 9-13. When the short-term 3-month interest rate is included with inflation and the ratio of public debt to nominal GDP, the computed F-statistics value is mostly higher than the upper bounds value. Long-run coefficients of the short-term interest rates are positive when significant. The magnitude of this coefficient lies between 0.13 to 0.53 . The debt-to-nominal-GDP ratio is mostly negative and significant at the 1 percent level, suggesting that in the long run a higher debt ratio tends to reduce the nominal yields of Indian government bonds, contrary to the conventional wisdom. Quarterly data allows the use of government finance variables but a clear limitation is that these results are based on a smaller number of observations.

\section{Table 9: ARDL Bounds Test Results for IGB2YR_Q (Quarterly Data)}

\begin{tabular}{|c|c|}
\hline Equation & F-statistics \\
\hline 4.31) IGB2YR_Q $=\gamma_{0}+\gamma_{1}$ TB3M_Q+ $\gamma_{2}$ DRATIO_Q & 2.67 \\
\hline 4.32) IGB2YR_Q $=\gamma_{3}+\gamma_{4}$ TCPIYOY_Q+ $\gamma_{5}$ DRATIO_Q & 1.68 \\
\hline 4.33) IGB2YR_Q $=\gamma_{6}+\gamma_{7}$ IPIYOY_Q+ $+\gamma_{8} D R A T I O \_Q$ & 2.21 \\
\hline 4.34) IGB2YR_Q $=\gamma_{9}+\gamma_{10}$ TB3M_Q $+\gamma_{11}$ TCPIYOY_Q $+\gamma_{12}$ DRATIO_Q & 1.16 \\
\hline 4.35) IGB2YR_Q $=\gamma_{13}+\gamma_{14}$ TB3M_Q $+\gamma_{15}$ IPIYOY_Q+ $\gamma_{16}$ DRATIO_Q & 2.03 \\
\hline 4.36) IGB2YR_Q $=\gamma_{17}+\gamma_{18}$ TB3M_Q+ $\gamma_{19}$ TCPIYOY_Q+ & 1.01 \\
\hline
\end{tabular}

Note: Lower bounds values are 6.84, 4.94, and 4.04 for 1 percent, 5 percent, and 10 percent levels of significance, respectively. Upper bounds values are 7.84, 5.73, and 4.78 for 1 percent, 5 percent, and 10 percent levels of significance, respectively. 
Table 10: ARDL Bounds Test Results for IGB3YR_Q (Quarterly Data)

Equation

F-statistics

\begin{tabular}{|c|c|}
\hline 4.37) IGB3YR_Q $=\gamma_{22}+\gamma_{23}$ TB3M_Q+ $\gamma_{24} \mathrm{DRATIO} \_\mathrm{Q}$ & $5.51^{* *}$ \\
\hline 4.38) IGB3YR_Q $=\gamma_{25}+\gamma_{26}$ TCPIYOY_Q+ $\gamma_{27}$ DRATIO_Q & 2.19 \\
\hline 4.39) IGB3YR_Q $=\gamma_{28}+\gamma_{29}$ IPIYOY_Q $+\gamma_{30} \mathrm{DRATIO} Q \mathrm{Q}$ & 2.51 \\
\hline 4.40) IGB3YR_Q $=\gamma_{31}+\gamma_{32}$ TB3M_Q+ $+\gamma_{33}$ TCPIYOY_Q+ $+\gamma_{34}$ DRATIO_Q & $6.17^{* *}$ \\
\hline 4.41) IGB3YR_Q $=\gamma_{35^{+}} \gamma_{36}$ TB3M_Q+ $\gamma_{37}$ IPIYOY_Q+ $\gamma_{38}$ DRATIO_Q & 2.21 \\
\hline 4.42) IGB3YR_Q $=\gamma_{39+} \gamma_{40} \mathrm{~TB} 3 \mathrm{M}_{-} \mathrm{Q}+\gamma_{41} \mathrm{TCPIYOY} \mathrm{Q}^{+}$ & 1.09 \\
\hline
\end{tabular}

Long-run Relationships

\begin{tabular}{lcc}
\hline Variable & Equation 4.37 & Equation 4.40 \\
\hline TB3M_Q & $0.53^{* * *}$ & $0.44^{* * *}$ \\
TCPIYOY_Q & $(0.07)$ & $(0.03)$ \\
IPIYOY_Q & - & 0.00 \\
DRATIO_Q & - & $(0.03)$ \\
& $-2.39^{* * *}$ & - \\
Constant & $(0.82)$ & 0.69 \\
& $7.36^{* * *}$ & $(0.61)$ \\
\hline
\end{tabular}

Number of Observations

48

34

Notes: $* * *$ and $* *$ represent 1 percent and 5 percent levels of significance, respectively. Standard errors are in the parenthesis. Lower bounds values are 5.15, 3.79, and 3.17 for 1 percent, 5 percent, and 10 percent levels of significance, respectively. Upper bounds values are 6.36, 5.52, and 4.14 for 1 percent, 5 percent, and 10 percent levels of significance, respectively. 
Table 11: ARDL Bounds Test Results for IGB5YR_Q (Quarterly Data)

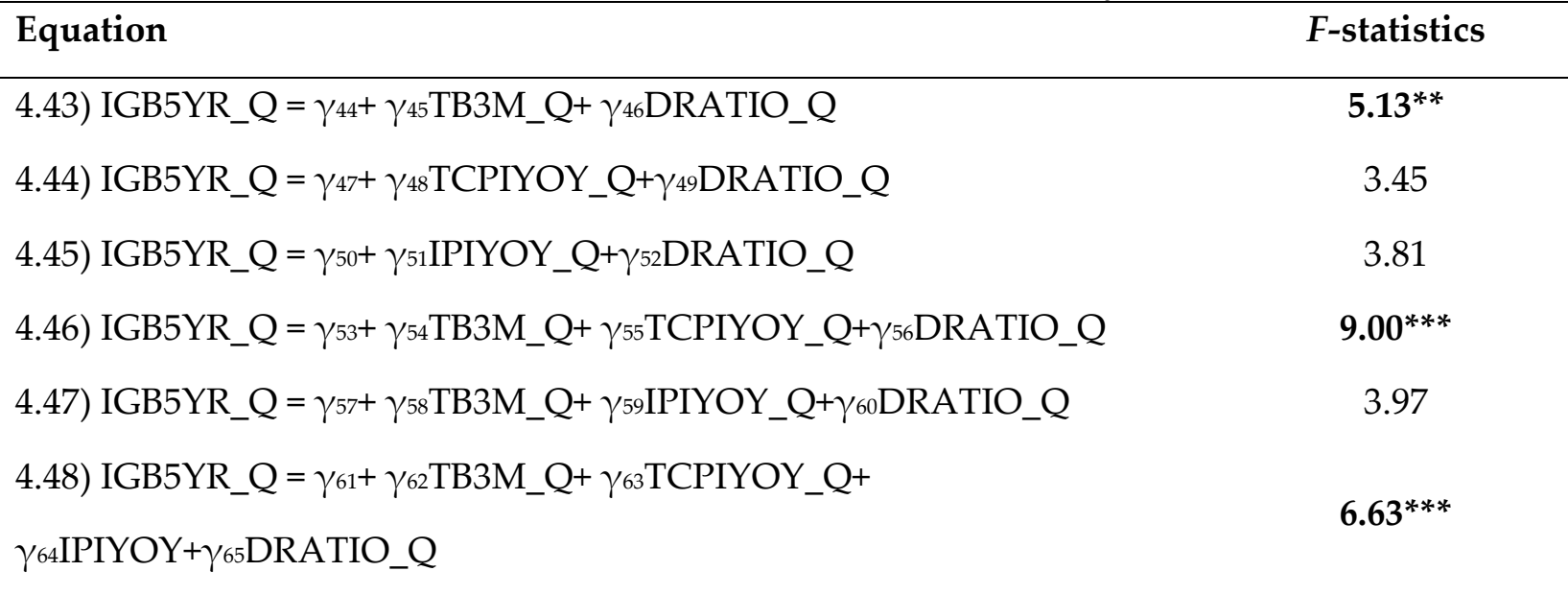

\section{Long-run Relationships}

\begin{tabular}{lccc}
\hline Variable & Equation 4.43 & Equation 4.46 & Equation 4.48 \\
\hline TB3M_Q & $0.41^{* * *}$ & $0.26^{* * *}$ & $0.21^{* * *}$ \\
TCPIYOY_Q & $(0.09)$ & $(0.04)$ & $(0.07)$ \\
& & -0.03 & -0.11 \\
IPIYOY_Q & - & $(0.05)$ & $(0.08)$ \\
& - & - & -0.03 \\
DRATIO_Q & $-3.06^{* * *}$ & 1.54 & $(0.02)$ \\
& $(1.04)$ & $(0.92)$ & 1.67 \\
Constant & $9.52^{* * *}$ & $3.73^{* *}$ & $(1.08)$ \\
& $(1.98)$ & $(1.36)$ & $4.67^{* *}$ \\
Number of Observations & 48 & 34 & $(1.83)$ \\
\hline
\end{tabular}

Notes: *** and ** represent 1 percent and 5 percent levels of significance, respectively. Standard errors are in the parenthesis. Lower bounds values are 5.15, 3.79, and 3.17 for 1 percent, 5 percent, and 10 percent levels of significance, respectively. Upper bounds values are 6.36, 5.52, and 4.14 for 1 percent, 5 percent, and 10 percent levels of significance, respectively. 
Table 12: ARDL Bounds Test Results for IGB7YR_Q (Quarterly Data)

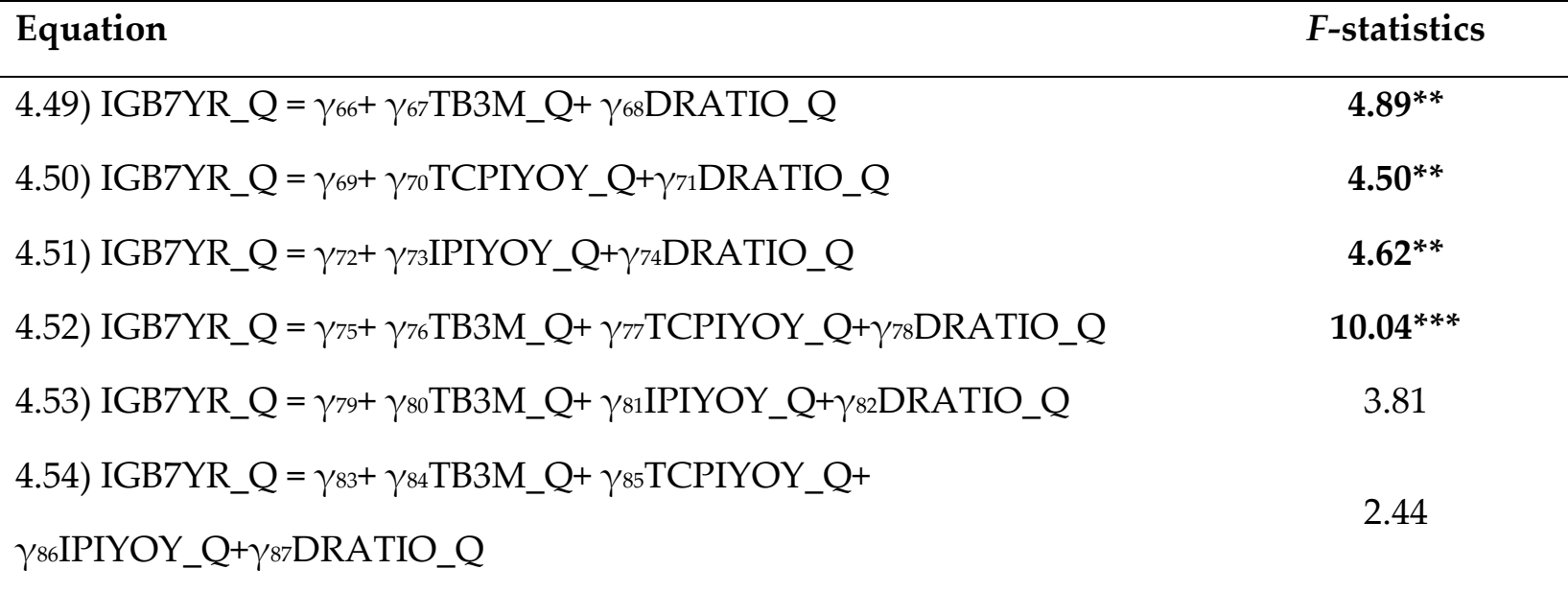

\section{Long-run Relationships}

\begin{tabular}{lcccc}
\hline Variable & Equation 4.49 & Equation 4.50 & Equation 4.51 & Equation 4.52 \\
\hline TB3M_Q & $0.35^{* * *}$ & - & - & $0.18^{* * *}$ \\
TCPIYOY_Q & $(0.10)$ & 0.02 & - & $-0.05)$ \\
& - & $(0.10)$ & -0.02 & $(0.05)$ \\
IPIYOY_Q & - & - & $(0.04)$ & - \\
& $-3.22^{* * *}$ & 1.67 & $-4.97^{* * *}$ & $1.71^{*}$ \\
DRATIO_Q & $(1.14)$ & $(2.16)$ & $(1.57)$ & $(0.98)$ \\
Constant & $10.40^{* * *}$ & 5.18 & $15.71^{* * *}$ & $4.27^{* * *}$ \\
& $(2.17)$ & $(3.51)$ & $(2.53)$ & $(1.43)$ \\
\hline Number of & 48 & 34 & 48 & 34 \\
Observations & & & & \\
\hline
\end{tabular}

Notes: ***, **, and * represent 1 percent, 5 percent, and 10 percent levels of significance, respectively. Standard errors are in the parenthesis. Lower bounds values are 5.15, 3.79, and 3.17 for 1 percent, 5 percent, and 10 percent levels of significance, respectively. Upper bounds values are 6.36, 5.52, and 4.14 for 1 percent, 5 percent, and 10 percent levels of significance, respectively. 
Table 13: ARDL Bounds Test Results for IGB10YR_Q (Quarterly Data)

\begin{tabular}{|c|c|}
\hline Equation & F-statistics \\
\hline 4.55) IGB10YR_ & $6.82^{* * *}$ \\
\hline $\mathrm{Q}=\gamma_{88}+\gamma_{89} \mathrm{~TB} 3 \mathrm{M} \_\mathrm{Q}+\gamma_{90} \mathrm{DRATIO} \_\mathrm{Q}$ & \\
\hline 4.56) IGB10YR_Q $=\gamma_{91}+\gamma_{92}$ TCPIYOY_Q+ $\gamma_{93}$ DRATIO_Q & $5.51^{* *}$ \\
\hline 4.57) IGB10YR_Q $=\gamma_{94}+\gamma_{95}$ IPIYOY_Q+ $\gamma_{96} \mathrm{DRATIO} Q \mathrm{Q}$ & $7.88^{* * *}$ \\
\hline 4.58) IGB10YR_Q $=\gamma_{97}+\gamma_{98} \mathrm{~TB} 3 \mathrm{M} \_\mathrm{Q}+\gamma_{99} \mathrm{TCPIYOY}+\gamma_{100} \mathrm{DRATIO} Q \mathrm{Q}$ & $10.66^{* * *}$ \\
\hline 4.59) IGB10YR_Q $=\gamma_{101}+\gamma_{102}$ TB3M_Q $+\gamma_{103}$ IPIYOY_Q+ $+\gamma_{104}$ DRATIO_Q & 4.14 \\
\hline 4.60) IGB10YR_Q $=\gamma_{105}+\gamma_{106}$ TB3M_Q+ $\gamma_{107}$ TCPIYOY_Q+ & 3.93 \\
\hline
\end{tabular}

Long-run Relationships

\begin{tabular}{lcccc}
\hline Variable & Equation 4.55 & Equation 4.56 & $\begin{array}{c}\text { Equation } \\
\text { Equation } 4.58\end{array}$ \\
\hline TB3M_Q & 0.29 & -57 & $0.13^{* *}$ \\
& $(0.20)$ & 0.03 & - & $(0.05)$ \\
TCPIYOY_Q & - & $(0.08)$ & -0.05 \\
& - & - & 0.04 & $(0.06)$ \\
IPIYOY_Q & $-5.41^{* * *}$ & 1.53 & $(0.07)$ & - \\
DRATIO_Q & $(2.18)$ & $(1.78)$ & $-7.52^{* * *}$ & $1.75^{*}$ \\
Constant & $14.67^{* * *}$ & $5.48^{*}$ & $19.90^{* * *}$ & $(1.02)$ \\
& $(4.42)$ & $(2.90)$ & $(3.56)$ & $(1.48)$ \\
\hline Number of & 64 & 34 & 64 & 34 \\
Observations & & & &
\end{tabular}

Notes: ***, **, and * represent 1 percent, 5 percent, and 10 percent levels of significance, respectively. Standard errors are in the parenthesis. Lower bounds values are 5.15, 3.79, and 3.17 for 1 percent, 5 percent, and 10 percent levels of significance, respectively. Upper bounds values are 6.36, 5.52, and 4.14 for 1 percent, 5 percent, and 10 percent levels of significance, respectively. 
These results reinforce the findings in Akram and Das's (2015a and 2015b) study, which reports that changes in the short-term interest rates are important determinants of changes in the longterm government bond yields in India. Whereas Akram and Das (2015a and 2015b) established the results for the short run, this study extends this for the long run.

\section{SECTION V: POLICY IMPLICATIONS AND CONCLUSIONS}

The empirical results support Keynes's conjecture that a central bank's actions, through its influence on short-term interest rates and its use of the tools of monetary policy, are the main drivers of long-term interest rates. In the case of India, the actions of the RBI affect the longterm interest rates. The long-term interest rates on IGBs are positively associated with the shortterm interest rates on Indian Treasury bills, after controlling for the relevant variables, such as the rate of inflation, the growth of industrial production, and the debt ratio. Higher (lower) longterm interest rates on IGBs are associated with higher (lower) short-term interest rates, higher (lower) rates of inflation, and a faster (slower) pace of industrial production. The results show that higher government indebtedness does not have an adverse effect on IGBs' nominal yields. These findings concur with the results obtained in Akram and Das's (2015a and 2015b) studies of short-term dynamics of IGBs, as well as in Chakraborty (2012) and Vinod, Chakraborty, and Karun's (2014) studies, both of which use quite different econometric and statistical methods.

The findings reported in this paper have implications for policy debates in India and other emerging markets with monetary sovereignty, which issue government debt mostly in its own currencies. The findings are also relevant for ongoing debates and controversies in fiscal policy, sustainability of government debt, monetary policy, monetary-fiscal coordination, policy mix during economic fluctuations, and macroeconomic and monetary theory (Bindseil 2004; Fullwiler 2008 and 2016; Kregel 2011; Sims 2013a and 2013b; Tcherneva 2011; Woodford 2001; and Wray 2003 and 2012). First, the results show that RBI can exert a strong influence on IGBs' yields by affecting the short-term interest rates. The RBI can affect the short-term interest rates on Indian Treasury bills through setting the repo rate and the reverse repo rate (see figure 2). These findings support Keynes's conjecture about the influence of a sovereign central bank 
on long-term interest rates. Second, the results also suggest that, contrary to the conventional wisdom, higher government indebtedness does not raise nominal yields of IGBs. While this finding is contrary to the conventional view, which is derived from the loanable funds perspective, it is in concordance with Keynesian and modern money theory (Fullwiler 2016; Wray 2003 and 2012), which holds that increased government expenditure results in a rise in the central bank's reserves and banking deposits in the financial system because the central bank credits the banks in the financial system in order to facilitate government borrowing and expenditures. Third, the results suggest that policymakers in India can use appropriate modelsbased on information on the current trend in short-term interest rates, government debt ratios, and other key macro variables - to form their long-term outlook about IGB yields and understand the implications of the government's fiscal stance on the government bond markets. Of course the use of such models requires judgement and prudence, and carries with it model risks and limitations.

Keynes claims that the central bank has a decisive influence on the long-term interest rates of government bonds. He believes that short-term interest rates and other monetary policy actions drive long-term interest rates and that the investor's long-run outlook is mostly shaped by the investor's near-term outlook and assessment of current conditions. This paper shows that Keynes's conjecture has empirical support in India over the long-run horizon. It extends Akram and Das's (2015a and 2015b) findings for the short-run horizon to the long-run horizon for the case of India. It contributes to the nascent literature - such as Akram (2014) and Akram and Das (2014a and 2014b) on Japan, and Akram and Li (2016 and 2017) on the United States — on this topic of examining whether Keynes's conjecture holds in various countries. Further research should extend this to a wider range of countries, both advanced capitalist economies and emerging markets and developing areas, and apply a broad spectrum of suitable econometric methods to establish whether these findings can be generalized and determine under which institutional contexts these findings are warranted. 


\section{REFERENCES}

Akram, T. 2014. “The Economics of Japan's Stagnation.” Business Economics 49(3): 156-75. http://dx.doi.org/10.1057/be.2014.19

Akram, T., and A. Das. 2014a. "Understanding the Low Yields of the Long-Term Japanese Sovereign Debt." Journal of Economic Issues 48(2): 331-40. http://dx.doi.org/10.2753/JEI0021-3624480206

— 2014b. "The Determinants of Long-Term Japanese Government Bonds' Low Nominal Yields." Levy Economics Institute Working Paper No. 818. Annandale-on-Hudson, NY: Levy Economics Institute of Bard College.

—. 2015a. "Does Keynesian Theory Explain Indian Government Bond Yields?" Levy Economics Institute, Working Paper No. 834. Annandale-on-Hudson, NY: Levy Economics Institute of Bard College.

- 2015b. "A Keynesian Explanation of Indian Government Bond Yields." Journal of Post Keynesian Economics 38(4): 565-87. http://dx.doi.org/10.1080/01603477.2015.1090294 (accessed November 25, 2016).

Akram, T., and H. Li. 2016. "The Empirics of Long-Term U.S. Interest Rates." Levy Economics Institute, Working Paper No. 863. Annandale-on-Hudson, NY: Levy Economics Institute of Bard College.

_ 2017. "What Keeps Long-Term U.S. Interest Rates So Low?" Economic Modelling 60(January): 380-90. http://dx.doi.org/10.1016/j.econmod.2016.09.017

Baldacci, E., and M. Kumar. 2010. "Fiscal Deficits, Public Debt, and Sovereign Bond Yields." IMF Working Paper No. 10/184. Washington, DC: International Monetary Fund. http://www.imf.org/external/pubs/ft/wp/2010/wp10184.pdf

Bindseil, U. 2004. Monetary Policy Implementation: Theory, Past, and Present. Oxford and New York: Oxford University Press.

Cassel, G. 1903. Nature and Necessity of Interest. London and New York: The Macmillan Company.

Chakraborty, L.S. 2012. "Empirical Evidence on Fiscal Deficit—Interest Rate Linkages and Financial Crowding Out." Levy Economics Institute Working Paper No. 744. Annandaleon-Hudson, NY: Levy Economics Institute of Bard College.

- 2016. Fiscal Consolidation, Budget Deficits and the Macro Economy. Thousand Oaks, CA: Sage Publications Pvt. Ltd. 
Clark, T.E., and T. Davig. 2008. "An Empirical Assessment of the Relationships among Inflation and Short- and Long-Term Expectations.” Research Working Paper RWP 08-05 (November). Kansas City: Federal Reserve Bank of Kansas City. https://www.kansascityfed.org/publicat/reswkpap/pdf/rwp08-05.pdf

Dickey, D.A., and W.A. Fuller. 1979. "Distribution of the Estimators for Autoregressive Time Series with a Unit Root." Journal of the American Statistical Association 74(366): 42731. http://dx.doi.org/10.1080/01621459.1979.10482531

_ 1981. "Likelihood Ratio Statistics for Autoregressive Time Series with a Unit Root." Econometrica 49(4): 1057-72. http://www.jstor.org/stable/1912517

Faust, J., and J.H. Wright. 2013. "Forecasting Inflation.” In Graham Elliot and Allan Timmermann (eds.), Handbook of Economic Forecasting, vol. 2A. Amsterdam: Elsevier.

Fullwiler, S. 2008. "Modern Central Bank Operations: The General Principles." Unpublished manuscript. Available at: http://ssrn.com/abstract=1658232 (accessed November 25, 2016).

—. 2016. "The Debt Ratio and Sustainable Macroeconomic Policy." World Economic Review 7(July): 12-42.

Gruber, J.W., and S.B. Kamin. 2012. "Fiscal Positions and Government Bond Yields in OECD Countries." Journal of Money, Credit, and Banking 44(8): 1563-87. http://dx.doi.org/10.1111/j.1538-4616.2012.00544.x

Hansen, L.P. 1982. "Large Sample Properties of Generalized Method of Moments Estimators." Econometrica 50(4): 1029-54. http://www.jstor.org/stable/1912775

Jácome, L.I., M. Matamoros-Indorf., M. Sharma., and S. Townsend. 2012. "Central Bank Credit to the Government: What Can We Learn from International Practices?" IMF Working Paper No. 12/16. Washington, DC: International Monetary Fund. https://www.imf.org/external/pubs/ft/wp/2012/wp1216.pdf

Johansen, S., and K. Juselius. 1990. "Maximum Likelihood Estimation and Inference on Cointegration - with Applications to the Demand for Money." Oxford Bulletin of Economics and Statistics 52(2): 169-210. http://dx.doi.org/10.1111/j.14680084.1990.mp52002003.x

Keynes, J.M. 1930. A Treatise on Money, Vol. II: The Applied Theory of Money. London: Macmillan.

- 2007 [1936]. The General Theory of Employment, Interest, and Money. New York: Palgrave Macmillan. 
Kregel, J. 2011. "Was Keynes' Monetary Policy À Outrance in the Treatise, A Forerunner of ZIRP and QE? Did He Change his Mind in the General Theory?" Levy Economics Institute, Policy Note No. 4. Annandale-on-Hudson, NY: Levy Economics Institute of Bard College.

Lam, R.W., and K. Tokuoka. 2013. "Assessing the Risks to the Japanese Government Bond (JGB) Market." Journal of International Commercial and Economic Policy 4(1): 1350002-1-1350002-15. http://dx.doi.org/10.1142/S1793993313500026

Marshall, A., 1890. Principles of Economics. London and New York: Macmillan and Company.

Macrobond. various years. Macrobond subscription services. (accessed May 31, 2016).

Mavroedis, S., M. Plagborg-Moller, and J.H. Stock. 2014. "Empirical Evidence on Inflation Expectations in the New Keynesian Phillips Curve." Journal of Economic Literature 52(1): 124-88. http://dx.doi.org/10.1257/jel.52.1.124

Nelson, C.R., and C.R. Plosser. 1982. "Trends and Random Walks in Macroeconmic Time Series: Some Evidence and Implications.” Journal of Monetary Economics 10(2): 13962. http://dx.doi.org/10.1016/0304-3932(82)90012-5

Pesaran, M.H., and Y. Shin. 1998. "An Autoregressive Distributed-Lag Modelling Approach to Cointegration Analysis.” Econometric Society Monographs 31: 371-413.

Pesaran, M.H., Y. Shin, and R.J. Smith. 2001. "Bounds Testing Approaches to the Analysis of Level Relationships.” Journal of Applied Econometrics 16(3): 289-326. http://dx.doi.org/10.1002/jae.616

Phillips, P.C.B., and P. Perron. 1988. "Testing for a Unit Root in Time Series Regression." Biometrika 75(2): 335-46. http://dx.doi.org/10.1093/biomet/75.2.335

Poghosyan, T. 2014. "Long-Run and Short-Run Determinants of Sovereign Bond Yields in Advanced Economies.” Economic System 38(1): 100-14. http://dx.doi.org/10.1016/j.ecosys.2013.07.008

Riefler, W.W. 1930. Money Rates and Money Markets in the United States. New York and London: Harper \& Brothers.

Sims, C. 2013a. "Paper Money.” American Economic Association Presidential Lecture, January 14. http://sims.princeton.edu/yftp/PaperMoney/PaperMoneySlides.pdf (accessed November 25, 2016). - 2013b. "Paper Money." American Economic Review 103(2): 563-84. http://dx.doi.org/10.1257/aer.103.2.563 
Taussig, F.W. 1918. Principles of Economics, volume 2 (second revised edition). New York: The Macmillan Company.

Tcherneva, P.R. 2011. "Bernanke's Paradox: Can He Reconcile His Position on the Federal Budget with His Recent Charge to Prevent Deflation?" Journal of Post Keynesian Economics 33(3): 411-34. http://dx.doi.org/10.2753/PKE0160-3477330301

Tokuoka, K. 2012. "Intergenerational Implications of Fiscal Consolidation in Japan." IMF Working Paper, No. 12/197. Washington, DC: International Monetary Fund. http://www.imf.org/external/pubs/ft/wp/2012/wp12197.pdf

Vinod, H.D., L. Chakraborty, and H. Karun. 2014. "If Deficits Are Not the Culprit, What Determines Indian Interest Rates? An Evaluation Using the Maximum Entropy Bootstrap Method." Levy Economics Institute Working Paper No. 811. Annandale-on-Hudson, NY: Levy Economics Institute of Bard College.

Woodford, M. 2001. "Fiscal Requirements for Price Stability." Journal of Money, Credit and Banking 33(3): 669-728. http://www.jstor.org/stable/2673890

Wray, L.R. 2003. Understanding Modern Money: The Key to Full Employment and Price Stability. Paperback edition. Cheltenham, UK and Northampton, MA: Edward Elgar.

- 2012. Modern Money Theory: A Primer on Macroeconomics for Sovereign Monetary Systems. New York: Palgrave Macmillan.

Yamanadra, S. 2014. "Minsky, Monetary Policy and Mint Street: Challenges for the Art of Monetary Policymaking in Emerging Economies." Levy Economics Institute, Working Paper No. 820. Annandale-on-Hudson, NY: Levy Economics Institute of Bard College. 